\title{
Gaziantep Duvar Resimlerinde İki Halk Sanatçısı: Bekir ve Şemsi
}

\author{
Two Folk Artists at Wall Paintings of Gaziantep: Bekir and Şemsi
}

\section{Yasemin ECESOY ${ }^{*}$}

Öz: Osmanlı İmparatorluğu'nda batıllış̧ma dönemiyle başlayan duvar resimleri, öncelikle İstanbul saray ve konakları olmak üzere, imparatorluk topraklarındaki tüm yapı türlerine hızla yayılmıştır. Bu yayılmadaki en büyük etken; İstanbul'da yaşamış ve özellikle payitahta yakın görevlerdeki kişilerin memleketlerine döndüklerinde, İstanbul'daki duvar resimlerinin benzerlerini yaşam alanlarına resmettirmeleridir. Gaziantep, coğrafi konumu bakımından çağlar boyunca ticaretin önemli noktalarından biri olmuştur. Gaziantep'te rastlanan duvar resimlerinin, yukarıda belirttiğimiz etkenin yanı sıra bölgedeki ticaretten etkilendiği ve şehir yapısına uygun bir şekilde farklı kültürleri yansıttığı anlaşılmaktadır. Osmanlı duvar resmi geleneğinin, Cumhuriyet uzantısı olarak Antep örneklerini incelediğimiz bu araştırmamızda, Antep genelinde 19. ve 20. yüzyıllarda yapılmış duvar resimleri olduğu tespit edilmiştir. Bu resimler; tanımlanabilir kent manzaraları, hayali manzaralar, konulu, figürlü panolar ve boyalı nakışlar olarak karşımıza çıkmaktadır. Kapsamlı bir çalışmanın bir bölümü olan bu makalede; Gaziantep İli, Şahinbey İlçesi’nde bulunan duvar resimli üç Antep evi incelenerek, Bekir ve Şemsi adlı iki halk sanatçısının eserleri değerlendirilmiş ve Anadolu'daki diğer halk sanatçılarının eserleriyle karşılaşıırılmıştır.

Anahtar sözcükler: Duvar Resmi, Gaziantep, Osmanlı, Cumhuriyet, Halk Sanatçısı

Abstract: The wall paintings beginning with the Westernization period at Ottoman Empire expanded into all kinds of building, especially the palaces and mansions in Istanbul. The leading motive in this expansion is the high concern of the people in having the very similar copies of the wall paintings in Istanbul paint at their residences when they returned homeland after having lived in Istanbul or hold office for a time at Ottoman court. Gaziantep has been one of the commercial centers for ages in terms of geographical location. It is concluded that the wall paintings in Gaziantep were influenced with the commercial activities in the region along with the motive mentioned earlier, and reflect the aspects of various cultures in accordance with the urban structure. Throughout this study, the main focus is on the wall paintings produced during the $19^{\text {th }}-20^{\text {th }}$ centuries in Gaziantep, all of which can be considered as the Republican reflection of Ottoman wall painting tradition. These paintings display such various contents as definable urban landscapes, fantastic landscapes, thematic and figurative panels, and painted embroidery. In this paper which consists of a single chapter of a broad study, three houses of Gaziantep with wall paintings have been examined, and the works of two folk artists, Bekri and Şemsi, have been evaluated along with a comprehensive comparison with the works of the other folk artists in Anatolia.

Keywords: Wall Painting, Gaziantep, Ottoman, Republic, Folk Artist

Suriye ve Anadolu arasında bir geçiş noktası konumunda nitelendirebileceğimiz Antep, kozmopolit bir kültür yapısına sahiptir. Şehir, İpek Yolu’nun Anadolu'daki ilk duraklarındandır ve birçok alışverişe şahitlik etmiştir. Bununla birlikte, sanatsal bakımdan da farklı kültürlerden

\footnotetext{
* PhD., Akdeniz Üniversitesi, Sosyal Bilimler Enstitüsü, Sanat Tarihi Bölümü, Antalya, y.ecesoy@outlook.com
} 
beslenen önemli bir cazibe noktası olmuştur. Coğrafi ve mimari açılardan Suriye/Halep’e yakın olan Antep, 14. yüzyılda, tarihçi Bedreddin Aynî zamanında da belirtildiği gibi "Arabistan'ın Gelinciği” adıyla anılmıştır. 1837 yıllarında bir keşif seyahatine çıkan İngiliz subayı ve seyyah Chesney ise burası hakkında:

“Antep Kalesi, dikkati çekecek kadar Halep Kalesi’ne benzemektedir. Birçok cami ve hamamdan başka iyi yapılmış 8000 Türk Evi ve 500 Ermeni Evi ihtiva etmektedir. Buranın Halep, Marass, Urfa ve İskenderun Limanı ile ticari münasebetleri vardır" şeklinde bilgi vermiş̧ir. Ayrıca Antep'te, Osmanlı Dönemi'nden günümüze ulaşan yirmi kadar han, ticaretin bu şehir için önemini göstermektedir (Güzelhan, 1959; Çam, 2006, XXI- XXXIV).

Farklı kültürlerin etkileşim alanları içinde şekillenen Antep, bulunduğu bölgeye yakın özellikler gösteren konut mimarisi örnekleri vermiş ve “Antep Evi”, Güneydoğu Anadolu konut mimarisinin önemli bir temsilcisi olmuştur (Ünal, 2007, 177). Malzeme ve süsleme bakımından Suriye/Halep ve Şam mimarlığından etkiler barındıran Antep evleri genellikle; yüksek avlu duvarları içerisinde iki katlıdır ve üst katlara ulaşım dışarıdan merdivenle sağlanmaktadır. Hayat da denilen ve evin kadınının günlük işlerini yapabileceği bir mekan olan avlu, tüm servis odalarına açılmaktadır. Üst katta eyvanlı bir girişin ardından genellikle iki oda bulunmaktadır. (Antep evleri ile ilgili ayrıntılı bilgi için bkz. Güzelbey, 1960, 4-14; Yener, 1960, 19-20; Aksoy, 1961, 21; Arpacioğlu, 16-17; 1961; Öztahtac1, 1961, 10; Ülkü, 1961, 21-23; Atalar, 2004; Anonim, 2005; Ünal, 2007, 177-199). Ayrıca Gaziantep, Müslümanların hac yolu üzerindeki duraklarından biridir. Buradan Şam'a geçilmesi, Gaziantep ile Şam'ın mimari ve süsleme özelliklerinin ortak yönlerini artırmıştır. Özelikle ticari bakımdan Mısır ile bağlantıları da bulunan Antep, kültürel bir etkileşimin sonucu olarak, Kahire ve Şam ile birlikte duvar resimlerinin görüldüğü önemli bir merkez haline gelmiştir. Kahire ve Şam'daki duvar resimleri üzerine yapılan bazı çalışmalar, buralarda etkin bir şekilde duvar resmi varlı̆̆ının göstergesidir (Renda, 1997, 91-105; Gürçağlar, 2002, 343-350; Weber, 2006; Germaner, 2011, 125-133; İnankur, 2011, 133-139).

Gaziantep/Şahinbey İlçesi’nde yer alan duvar resimleri, resimlerin işlendiği konutların bulunduğu bölgeye göre farklı üslup özellikleri göstermektedir. Osmanlı Dönemi Antepi’nde, genellikle Ermenilerle meskun olan Bey Mahallesi’ndeki konak tarzı gösterişli konutlarda yer alan duvar resimlerinin konusu, İstanbul ve Avrupa'yla ilgili kent tasvirleri ve figürlü kompozisyonlardır. Fotoğraftan yararlanılarak çalışıldığı kesin olarak tespit edilen bu resimler, Antep'in hem payitaht İstanbul'la hem de ticari açıdan Avrupa ile ilişkilerini göstermesi açısından önemlidir (Kalender, 1999; Tekinalp, 2013, 679-686. Bey Mahallesi'nde bulunan ve daha önce kısmen incelediğimiz Nehir Evi ile ilgili detaylı araştırmalarımızı bir başka çalışmamızda yayınlayacağız. Ecesoy, 2011, 253-270).

Türk/Müslümanlarla meskun Türktepe, Şekeroğlu, Tişlaki, Karagöz, Bostancı ve Suyabatmaz Mahalleleri'ndeki konutlarda yer alan duvar resimlerinde, halk sanatçılarının resmettiği az sayıda figürlü, tanımlanabilir ve hayali kent manzaralarından oluşan eserler bulunmaktadır. Görüldüğü gibi resimlerin konusu, yerleşim merkezlerine göre şekillenmiştir. Bu araştırmamızda, bahsettiğimiz ikinci bölge içinde yer alan Karagöz, Bostancı ve Suyabatmaz Mahalleleri’nde tespit ettiğimiz üç Antep evindeki duvar resimlerini değerlendireceğiz.

İnceleyeceğimiz ilk duvar resimli ev; Karagöz Mahallesi, Sadık Daî Sokak, No: 18'de bulunan ve günümüzde Büyükşehir Belediyesi Emine Göğüş Gaziantep Mutfak Müzesi olarak 
hizmet veren bir konaktır. Kitabesinden anlaşıldığı kadarıyla 1 Temmuz 1904 yılında Kethüdazâde Efendi tarafından yaptırılmıştır. Müze tanıtım katoloğundan alınan bilgiye göre; "Dünya durdukça ve sabah akşam döndükçe izzet ve şerefle bu makam daima mamur olsun, Allah İbrahim Efendi'ye bu mekânı devaml mübarek kılsın. Doğrusu gönül alan bu lalam evi güzel bina oldu" (1 Temmuz 1904) mealinde kitabesi bulunmaktadır. Ayrıca burası, Türkiye'nin ilk Turizm Bakanı, aynı zamanda Gaziantepli siyasetçi ve gazeteci Ali İhsan Göğüş’ün doğduğu evdir. Ali İhsan Göğüş, binanın Emine Göğüş Mutfak Müzesi haline getirilmesi şartıyla Gaziantep Müze Müdürlüğü’ne bağışlamıştır (Anonim, 2005, 285; Çayan, 2012, 85-87).

Kesme taştan inşa edilmiş iki katlı evin, üst kat odalarının tavanlarında, bitkisel öğeler içe-

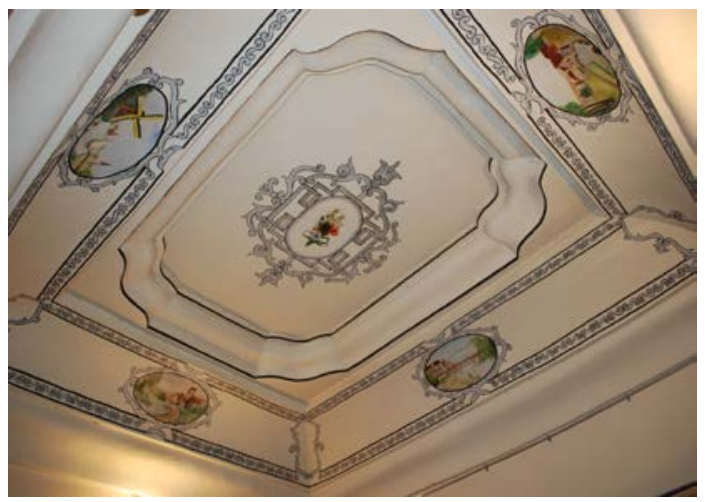

Fig. 1. Göğüş Evi/Göğüş Odası Genel Görünüm. ren boyalı nakışlar ve manzara konulu duvar resimleri yer almaktadır. Üst katta "Gögǚs Odası" adıyla anılan odanın tavanında, madalyon içinde Avrupa şehirlerini anımsatan dört manzara resmi bulunmaktadır (Fig. 1).

Gögüş Odası'nda inceleyeceğimiz ilk resimde, nehir kıyısında kasır görünümlü bir bina tasvir edilmiştir. Bu bina, yüksek kırma çatısı ve üzerinde bayrak dalgalanan kulesiyle, Anadolu veya İstanbul'dan çok Avrupa şehirlerini çağrıştırmaktadır. Yapının karşı kıyısına, manzaradaki denge bütünlüğünü sağlamak için büyük bir ağaç yerleştirilmiştir (Fig. 2). İkinci resimde görülen nehrin, seyirciye göre soluna büyük bir değirmen, sağına ve arka planına -birinci resimdekine benzer- kuleli iki yapı tasvir edilmiştir. Nehirde, ayakta bir figürün yer aldığ 1 yelkenli

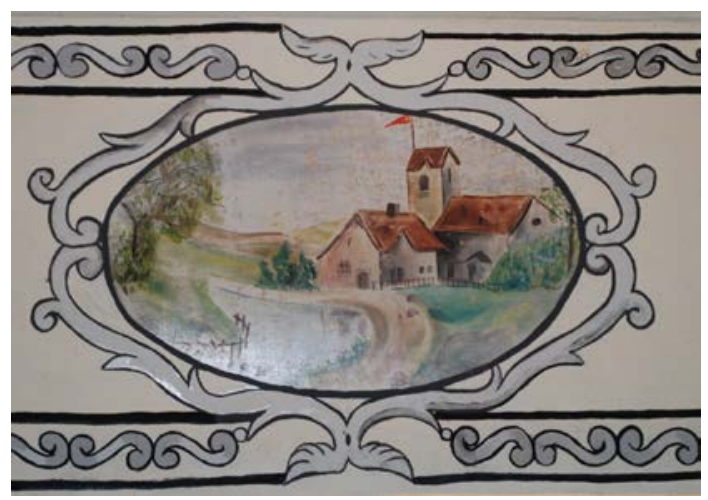

Fig. 2. Göğüş Evi/Göğüş Odası Manzara Tasviri. gemi dikkati çekmektedir. Resmin iki tarafına ağaç ve çiçeklerden oluşan çeşitli doğa unsurları yerleştirilse de, bu öğeler perspektif bakımından manzaraya yardımcı olamamıştır (Fig. 3). Üçüncü resimde, patika yoldan gidilen ve köprüden geçilerek ulaşılabilinen yüksek kırma çatıllı, üzerindeki silmeler ile hareketlendirilmiş başka bir ev görülmektedir. Burada, Fig. 3'teki değirmen başka bir açıdan resmedilmiştir (Fig. 4). Dördüncü resmin merkezine üç kemerli bir köprü yerleştirilmiştir. Köprünün solunda kırma çatılı benzer yapılar, sağında ise görsel bütünlüğü tamamlayan ağaçlık bir alan yer almaktadır. Ayrıca, odadaki diğer manzaralardan farklı bir biçimde burada güneş parlamakta ve sanatçı imzası olan "Şemsi" yazısı okunabilmektedir (Fig. 5). Dört resimde de yer alan nehir, değirmen ve benzer yapıların bulunması, manzaraların aynı bölgeyi betimlediğini düşündürmektedir. Tavan göbeğinde, dönemin özelliklerini yansıtan "S" ve "C" kıvrımların ve geometrik süslemelerin iç içe geçtiği bir başka madalyon oluşturulmuştur. Madalyonun içinde çeşitli türlerden bir demet çiçek motifi yer almaktadır (Fig. 6).

Günümüzde "Misafir Ă̆ırlama” (Fig. 7-8) ve “Özel Gün Yemekleri” (Fig. 9) adıyla bilinen odaların, tavanlarının dört köşesinde bitkisel süslemeler görülmektedir. Ayrıca, "Özel Gün Yemekleri" odasının tavan eteğinde, bir güvercin, gonca güle bağlanmış kurdeleyi çekiştirirken tasvir edilmiştir (Fig. 10). 


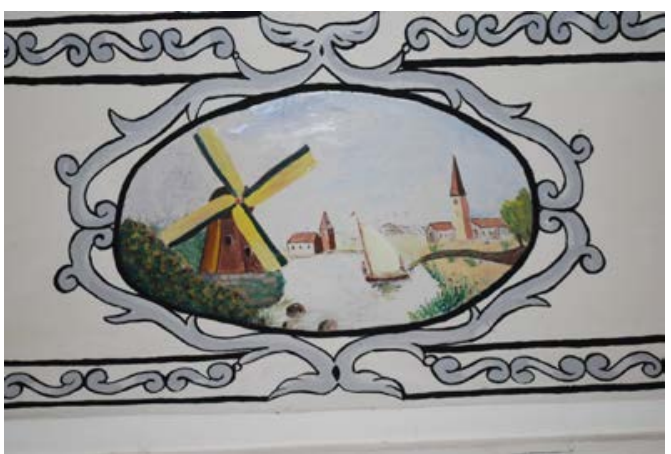

Fig. 3. Göğüş Evi/Göğüş Odası Manzara Tasviri.

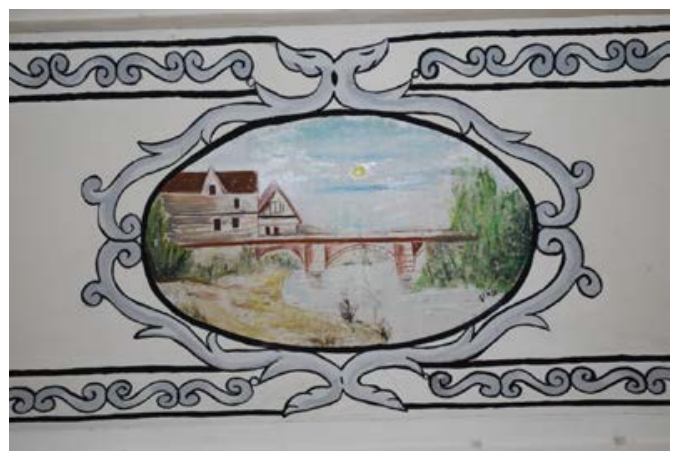

Fig. 5. Göğüş Evi/Göğüş Odası Manzara Tasviri.

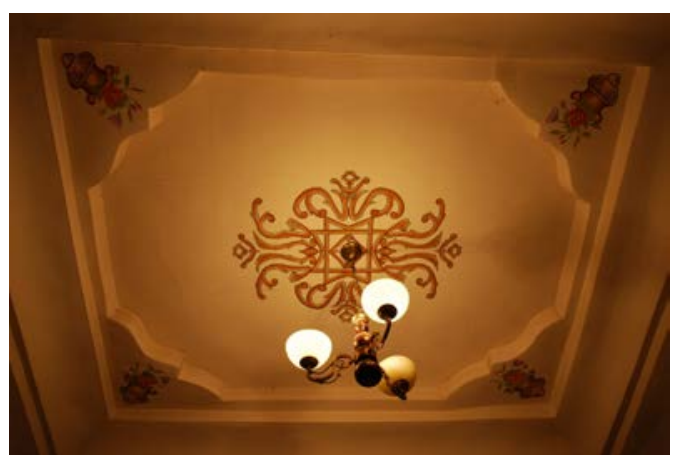

Fig. 7. Gögü̧ş Evi/Misafir Ağırlama Odası. Genel Görünüm

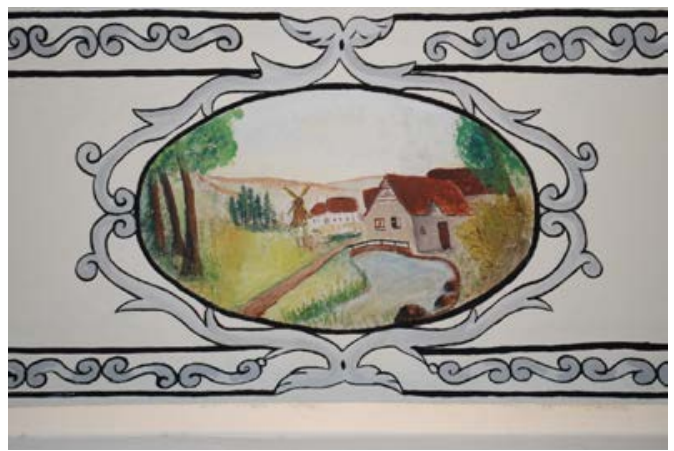

Fig. 4. Göğüş Evi/Göğüş Odası Manzara Tasviri.

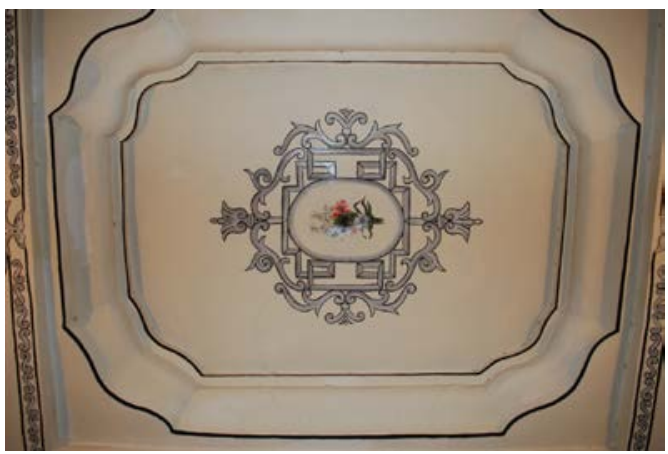

Fig. 6. Göğüş Evi/Göğüş Odası Tavan Göbeği.

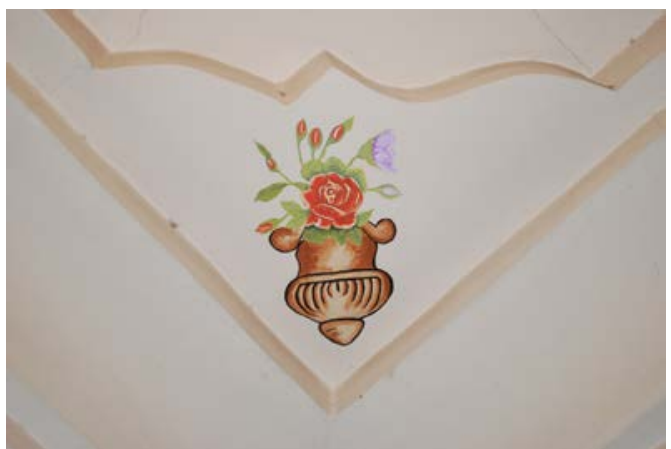

Fig. 8. Göğüş Evi/Misafir Ağırlama Odası Detay.

İnceleyeceğimiz ikinci duvar resimli ev; Bostancı Mahallesi, Mektep Sokak, No: 2'de bulunan, iki katlı, kesme taştan inşa edilmiş bir yapıdır. İkinci kattaki evin girişine, dışarıdan merdivenle ulaşılmaktadır (Çayan, 2012, 83-84). Duvar resimlerinin yer aldığı mekan, evin diğer odalarına oranla birkaç basamak yüksektedir. Misafirlerin ağırlandığı bir yer olduğunu anladığımız köşk biçimindeki mekanın tavanı, aynalı tonoz formunda tasarlanmış, kubbemsi bir şekilde örtülmüştür. Dikdörtgen bir göbekten duvarlara doğru geniş tutulan tavan etekleri, saç levha ile kaplanmıştır. Tavan göbeğinde ve dört eteğinde madalyon içinde manzara resimleri görülmektedir (Fig. 11).

Tavan göbeğinde, Barok üsluptaki bezemelerle çerçevelenmiş bir resim yer almaktadır. $\mathrm{Bu}$ resim, nehir kenarına konumlanmış, çeşitli yapılardan oluşan hayali bir manzara tasviridir (Fig. 12). Nehrin üzerinde yelkenli bir gemi bulunur. Manzaranın, kalın firça vuruşlarıyla acemice resmedildiği görülmektedir. Geç dönemde, resim üzerine bir aydınlatma unsuru kullanılmış, levha yüzeyi eğilmiş ve resim tahrip olmuştur. 
Tavan eteğinde inceleyeceğimiz oval formdaki resimlerden ilkinde; piramitleri ve Nil Nehri ile Mısır betimlenmiştir (Fig. 13). Nehrin iki tarafında, coğrafyanın bitki örtüsüne uygun olarak palmiyeler ve hurma ağaçları görülmektedir. Resmin seyirciye göre sol kısmında bir çadır bulunmaktadır. Bu çadırdan nehre doğru yönelen patikanın sonunda, elinde sepetleriyle bir kadın figürü yer almaktadır. Piramitler, kuşlar ve ağaç tasvirlerindeki gölgelendirmelere rağmen, manzaranın genelinde, sanatçının muhtemelen resim eğitiminin olmadığına işaret eden bazı perspektif eksiklikleri gözlemlenebilmektedir.

İkinci resimdeki manzarada, seyirciye göre solda bir nehir (ya da göl) bulunmaktadır (Fig. 14). Sağ bölümde ise patika yolla ulaşılabilen iki mesken görülür. Patika yolun başında, saçları iki yandan örülmüş bir kız çocuğu resmedilmiştir. Figürün bir eli başının arkasında, diğer eli belindedir. Ancak, bu resmi, odadaki diğer manzaralardan daha önemli kılan unsur, sanatçı imzası olan "Bekri” ibaresi yer almasıdır.

Üçüncü resmin merkezine bir nehir yerleştirilmiştir (Fig. 15). Nehrin seyirciye göre sol bölümünde ağaçlar, sağ bölümünde ise diğer resimlerdeki aynı mimari özelliklere sahip bir ev vardır. Ev tasvirinin giriş bölümünde, başlangıcının iki

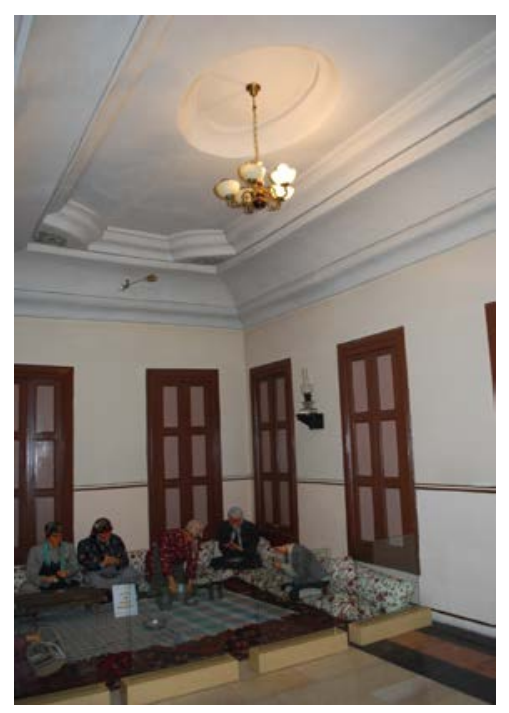

Fig. 9. Göğüș Evi/Özel Gün Yemekleri Odası Genel Görünüm. yanında saksı bulunan bir merdiven görülmektedir. Ağaçlarların arkasında ve ufuk çizgisi üzerinde beliren güneşin yansıması nehre düşmektedir. Nehirde, güneşle aynı renk tonlarına sahip kuğular yüzmektedir. (Kuğu tasvirleri aynı sanatçının yaptığı ve bundan sonra inceleyeceğimiz evin duvar resminde de yer almaktadır). Fig. 14'te rastladığımız, ağaç üzerine tünemiş ve uçan

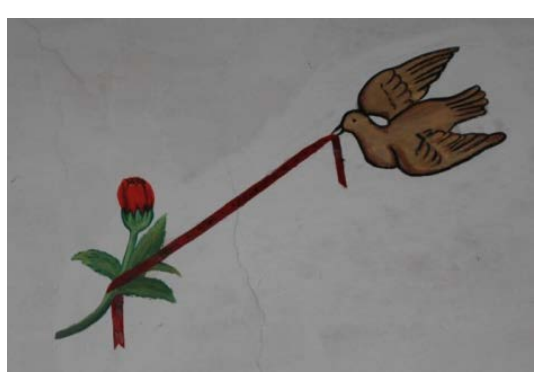

Fig. 10. Gögü̈ş Evi/Özel Gün Yemekleri Odası Detay. kuşlar aynı kompozisyonla burada da karşımıza çıkmaktadır. Evin arkasında görülen ağaçların farklı renk tonlarıyla betimlenmesi, sanatçının manzara içerisinde aradığı atmosferi yakalamasına yardımcı olmaktadır.

Bu evde inceleyeceğimiz son manzara resmi, dağlar ve nehir (ya da deniz) üzerine yansıtılan sşık oyunları sebebiyle, görsel açıdan diğerlerinden daha zengindir (Fig. 16). Burada, tavan göbeğindeki yelkenli gemi tasvirine oranla, daha ince işçilikli bir yelkenli tasviri vardır. Resmin sol bölümüne, patika yol ile ulaşılabilen bir ev görülmekte ve yolun başında, elinde bastonuyla yaşlı bir erkek figür yer almaktadır. Bu figür bıyığı ve şapkasıyla daha çok bir Avrupalıyı anımsatmaktadır.

Son olarak inceleyeceğimiz ev; Suyabatmaz Mahallesi, Müftüoğlu Sokak, No: 5’tedir. H.1316 (1900) tarihli bu yap1; "L" planlı, iki katlı ve kesme taştan inşa edilmiştir (Anonim, 2005, 542). Evin özellikle bir odası oldukça zengin bir süslemeye sahiptir (Fig. 17). Saç kaplama tavan, bitkisel süslemeli çeşitli bordürlerle çerçevelenmiştir. Tavan göbeğinde, "S" ve "C" kıvrımlarıyla birlikte çiçek ve nar betimlemeleri; tavan eteğinin dört köşesinde ise hayali manzara tasvirleri yer almaktadır (Fig. 19). Ancak, bu odada dikkati en çok çeken süsleme unsuru, iki kat çerçeve ile sınırlandırılmış duvar resmidir (Fig. 20). Resmin alt bölümündeki kuğuların ağzında, bir önceki evde rastladığımız sanatçının "Bekir" isminin harfleri ve Osmanlıca rakamlar ile 1351 (1935) tarihi okunmaktadır. Aynı şekilde, tavan göbeğinin süslemeleri arasında “1351” ve "Bekri” yazmaktadır (Fig. 18). 
Sanatçının hangi dönemde yaşadığını öğrenmemiz açısından tarih vermesi oldukça önemlidir. Böylece, bu iki evin duvar resimleri ve kalem işi süslemelerinin aynı sanatçı tarafından, birbirlerine yakın tarihlerde yapıldı $\breve{1}$ anlaşılmaktadır.

Duvar resminde, sanatçının diğer tüm resimlerinde gözlemlenen nehir (ya da deniz) yer alır. Nehir, resmin alt kısmında daralmakta, arka planda genişlemektedir. Resmin seyirciye göre solunda, kasır görünümündeki üç katlı büyük bir yapı, yanında müştemilat olduğunu düşündügümüz daha küçük bir mesken ile birlikte betimlenmiştir. Sanatçı, büyük yapının girişine anıtsallık katmaya çalışmıştır. Bunu, özellikle alınlık ve altındaki bitkisel süslemeler ile yaratmıştır. Ayrıca, çatı bölümünde alemler vardır. Yapının seyirciye dönük cephesi, nehre doğru giden mor sarmaşık çiçeklerle süslenmiş, kemerli görünüme sahip bir geçit ile vurgulanmıştır. Sanatçının diğer eserlerinde olduğu gibi yapının girişine patika yoldan ulaşılmakta ve yolun başında, çivit mavisi eteği ve şapkası (ya da başörtüsü) ile dikkati çeken bir kadın figürü bulunmaktadır. Bu figür, Bekir'in diğer evde resmettiği, bir eli başının arkasında diğer eli belinde olan figürün duruşuyla aynı şekilde resmedilmiştir (Fig. 14).

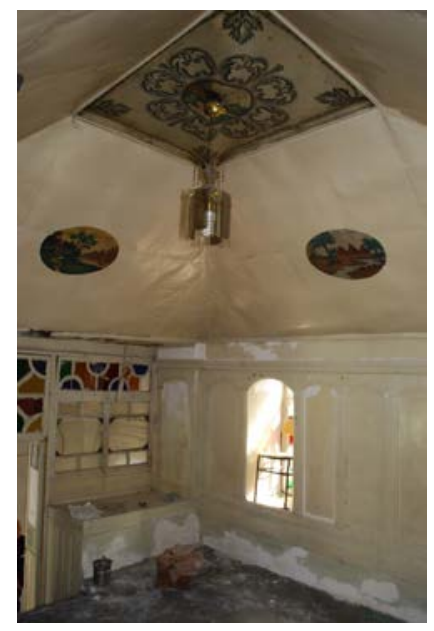

Fig. 11. Bostancı Mahallesi, Mektep Sokak, No: 2 Genel Görünüm.

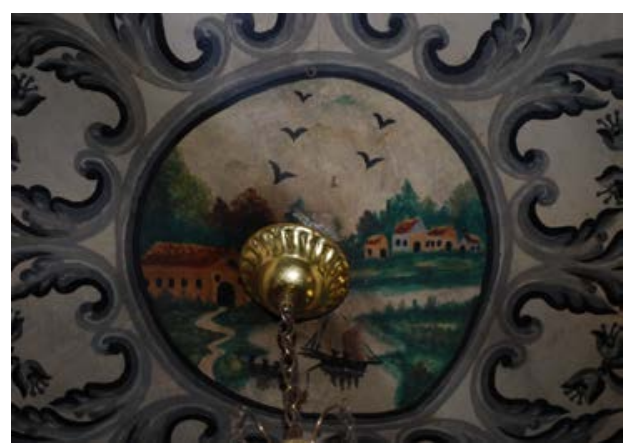

Fig. 12. Bostanc1 Mahallesi, Mektep Sokak, No: 2 Tavan Göbeği.

Nehirde, ayrıntılı resmedilmiş bir yelkenli gemi ve ona göre simetrik konumda çizilmiş iki sandal görülür. Sandalların üzerine martı benzeri su kuşları konmuştur. Yelkenli üzerinde ise üç insan silüeti seçilmektedir. Bunlardan birisi -patika yolun başında el sallayan kadın göz önünde bulundurulursa- yelkeni açmakta, ikisi oturmaktadır. Sanatçının hayal dünyasında, belki de patika yolun başında bekleyen kadın figürü, bu yelkenlideki insanları uğurlamaktadır.

\section{Değerlendirme}

Osmanlı İmparatorluğu'nda, Batılılaşma döneminde görülmeye başlayan duvar resimleri, başta İstanbul'daki saray ve konaklar olmak üzere Anadolu, Balkan ve Ortadoğu'daki tüm mimari yapılara yayılmıştır. Osmanlı dönemi geleneksel bezeme biçimi olan geometrik ve bitkisel süsleme, bu dönemde giderek yerini manzara, natürmort ve figürlü süslemeye bırakmıştır. Özellikle Anadolu'da, tanımlanabilir ve hayali kent manzaraları önemli bir yere sahiptir (Renda, 1977; Renda, \& Erol, 1980; Arık, 1988; Tekinalp, 2002, 440-447).

Duvar resmi sanatçıları hakkında edinilen bilgi oldukça azdır. Osmanlı Dönemi, İstanbul'daki duvar resimleri; minyatür nakkaşları, son dönemde Avrupa'ya eğitime gönderilmiş tuval resmi sanatçıları veya çeşitli nedenlerle İstanbul'u ziyarete gelen yabancı sanatçılar tarafından yapılmış olmalıdır. Anadolu'da görülen sanatçıların çoğu ise genellikle kendi yörelerine has üsluplarıyla eserlerini ortaya koyan, resim eğitimi almamış halk sanatçılarıdır. İstanbul'da, herhangi bir sebepten dolayı bulunmuş ve payitahta yakın bazı kişiler memleketlerine döndüklerinde, bu halk sanatçılarından, İstanbul saray ve konaklarında gördükleri duvar resimlerine benzer resimler istemesi ihtimal dahilindedir. 


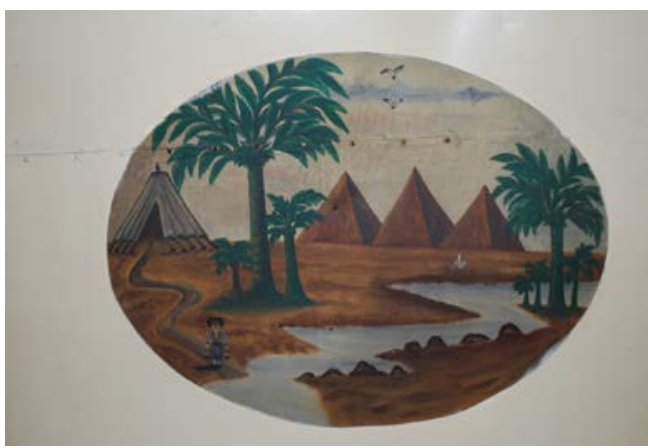

Fig. 13. Bostanc1 Mahallesi, Mektep Sokak, No: 2 Misır Tasviri.

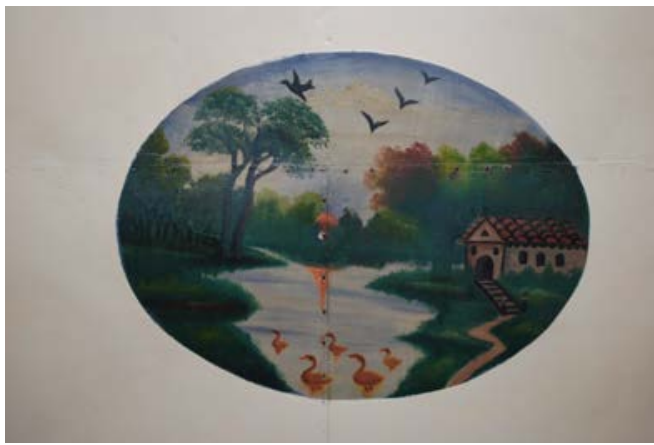

Fig. 15. Bostanc1 Mahallesi, Mektep Sokak, No: 2 Manzara Tasviri.

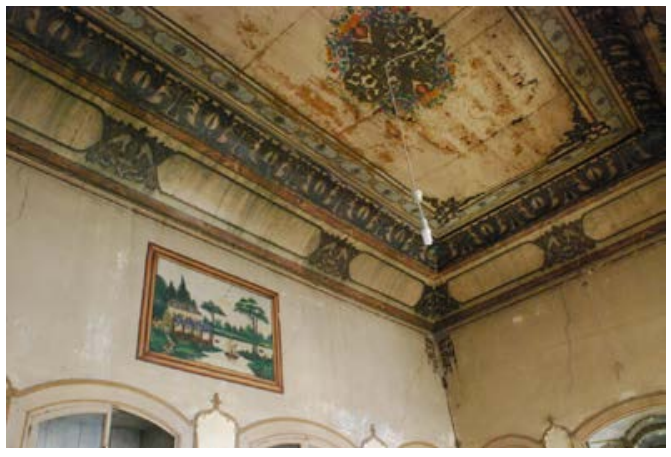

Fig. 17. Suyabatmaz Mahallesi, Müftüoğlu Sokak, No: 5 Genel Görünüm.

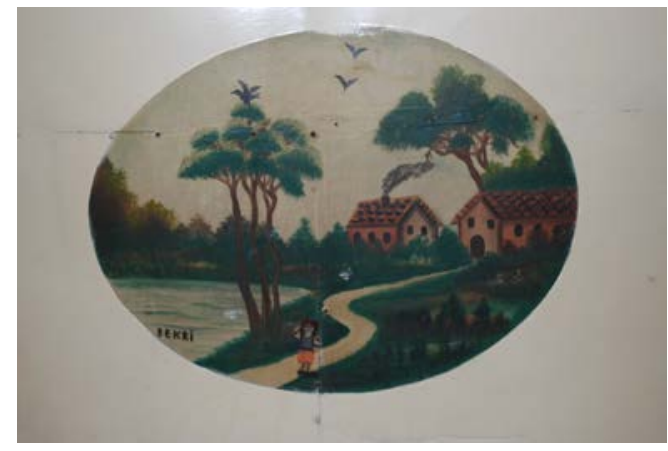

Fig. 14. Bostanc1 Mahallesi, Mektep Sokak, No: 2 Manzara Tasviri.

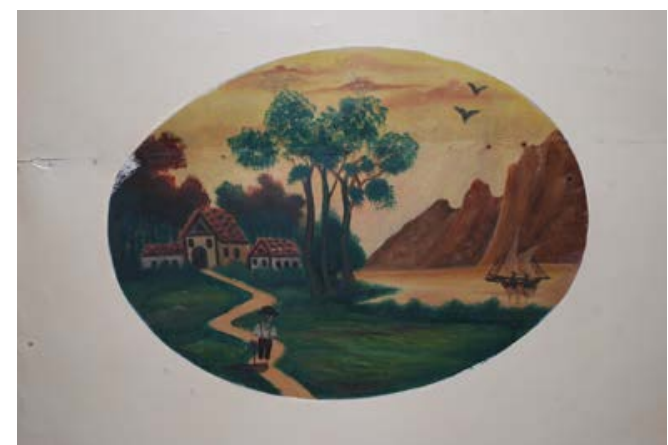

Fig. 16. Bostanc1 Mahallesi, Mektep Sokak, No: 2 Manzara Tasviri.

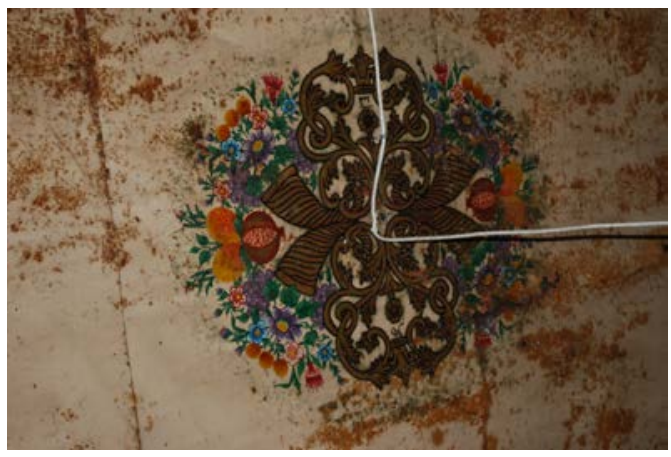

Fig. 18. Suyabatmaz Mahallesi, Müftüoğlu Sokak, No: 5 Tavan Göbeği.

Anadolu halk sanatçılarından bazılarına kısaca değinerek, bunlarla, incelediğimiz iki halk sanatçısı arasında bazı paralellikler kurulabileceğimizi düşünüyoruz. Mehmet Hulusi, İstanbul'da yaşamış ve bilinen en eski halk sanatçısı ve litografi ustasıdır (Aksel, 2010, 246-253). Sanatçı, II. Abdülhamid zamanında yaşamış ve Mamuretü'l-Aziz diye anılan Harput Kasabası'nda doğmuştur. İstanbul'a gelerek Darülmuallimin'de okumuş, Mekteb-i Mülküye'yi bitirmiştir. Daha sonra Rufai tarikatına girerek bu tarikata ve Bektaşilik'e dair resimler ortaya koymuştur. Sanatçı, kendi adını verdiği Mehmed Hulûsi Matbaası'nda taşbaskı resimler basıp çoğaltmıştır. Mehmed Hulûsi'nin bazı resimlerinde adı ve imzası yer almaz. Resimlerinden bir kısmını, matbaasında çalışan Arif ve Mustafa gibi başka halk ressamları üretmiştir. Sanatçı; Çanakkale, İstanbul, Kudüs, Kahire ve Misır gibi mühim kentlerin resimlerini çizmiş, taşbaskılarını basmış ve duvar resimlerini yapmıştır (Aksel, 1974, 15-18; Arık, 1988, 99-101; Pınarbaş1, 2001, 14-15; Aksel, 2010, 246-253). 
Anadolu'daki halk sanatçılarından Miralayzade Ali Bey (1861-1839), Elâzığ ${ }^{‘}$ da Hüseynik (Ulukent) Köyü’nde yer alan ve günümüzde Çağlayan Ailesine ait evin havuzbaşındaki Harput ve İstanbul tasvirlerini 1890 y1lında resmetmiştir ve bilinen tek eseri budur (Sözen, 1972, 31-33; Arık, 1988, 97-98; Arslan, 2010, 157-177).

Nevşehir/Göreme Mehmet Paşa Konağı'nın, başodasının pencere pervazında bir tür nazar duası şeklinde yazılmış şiir ve "Enşere (inşa) Sivaslı El-Şeyh Osman Efendi, Sene 1244” ibaresine rastlanmaktadır. Bu imza duvar resimleri üzerinde yer almasa da, resimlerde kullanılan boyayla yazıldığı görülmüştür. Konağın duvar resimleri İstanbul-saray üslubu göstermektedir. Bu nedenle sanatçının İstanbul'daki duvar resimlerini görmüş olduğu düşünülmektedir (Renda, 1986, 103-118; Ecesoy, 2011, 121-125).

Anadolu duvar resimlerinde önemli bir yer tutan ve hakkında en çok bilgiye sahip olduğumuz halk sanatçısı Zileli Emin'dir. Mahlasından da anlaşılacağı gibi sanatçı, Tokat'ın Zile İlçesi'nde doğmuş, eserlerini 1875 yılları civarında resmetmiştir. Zileli Emin'in duvar resimleri, Amasya ve Tokat civarındadır. Kesin olarak bilinen eserleri; Amasya Gümüşlü Camii, Amasya/ Merzifon Kara Mustafa Paşa Camii Şadırvanı, Amasya II. Bayezid Camii Şadırvanı ve Tokat/ Zile Şeyh Nusreddin Türbesi'dir. Kendisi, Mehmet Hulusi gibi tarikat çevresinde yetişmiş ve halk kültüründe büyümüş bir sanatçıdır. Sanatçı; "Zileli Emin, Arapzâde Emin Usta, Arap oğlu Ak Emin” gibi mahlasları kullanmıştır. Eserlerinde; İstanbul, Hayber, Karadağ ve Horasan gibi yer tasvirlerinin yanı sıra tarikat, ordu, hilafet, saltanat ve Batılılaşmayı simgeleyen imgelere rastlanır (Arık, 1975, 8-13; Çal, 1987, 427-459; Cantay, 1980, 497-503; Tanman, 1993, 491-521).

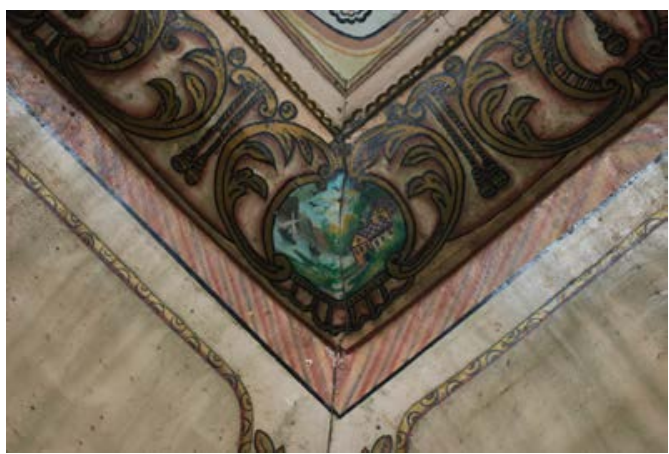

Fig. 19. Suyabatmaz Mahallesi, Müftüoğlu Sokak, No: 5 Tavan Eteğindeki Manzara Tasviri.

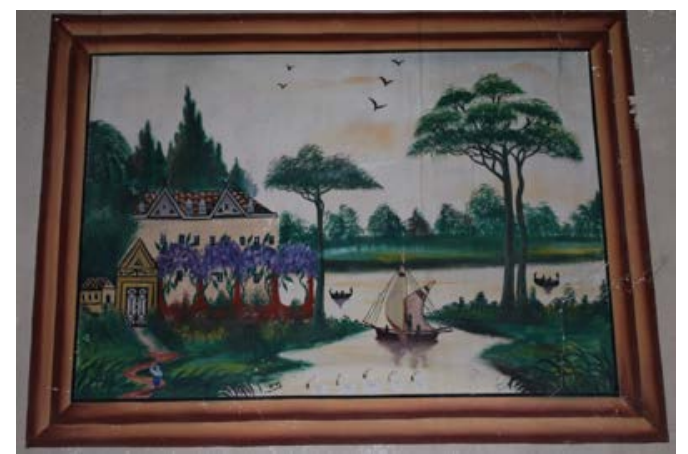

Fig. 20. Suyabatmaz Mahallesi, Müftüoğlu Sokak, No: 5 Manzara Tasviri.

Halk sanatçısı tabiri sadece Müslüman ya da Türk kavramlarını içermemektedir. Bunun en güzel örneği Nevşehir/Ürgüp/Mustafapaşa Kasabası'nda doğan ve buradaki birçok konutu duvar resimleri ile süsleyen, aynı zamanda halk müzisyeni ve komedyen olan Rum asıllı Kostis Meletiyadis'dir. Sanatçının, İstanbul'da bulunduğu, buradan gizlice bir gemi ile İtalya'ya kaçtığı ve resim eğitimini Roma ve Venedik'te aldığ 1 bilinmektedir. Sanatçı, duvar resimlerinde mitolojik ve askeri konulu figürlü tasvirlere ve kent manzaralarına yer vermiştir. 1920 yılı civarında yaşamını yitiren sanatçı, halk sanatçılarının Avrupa gibi Anadolu dışındaki coğrafyalarda bulunabildiklerini göstermesi açısından önem arz etmektedir (Meletiyadis ile ilgili bilgileri yaşadığı dönemde, kasabanın Belediye Başkanı Sefarim Rizos'un oğlunun el yazmalarından öğrenmekteyiz (Özbek, 2005, 20-31, 37-46; Balta, 2007, 147; Pekak, 2010, 77-100).

Gaziantep’te duvar resmi yapan sanatçılar incelendiğinde, genellikle gayrimüslümlerin yaşadığı Bey Mahallesi'nde, yerel halk sanatçıların yanı sıra İtalya ve İstanbul'dan getirtilen sanatçıların da resimler yaptıkları görülmektedir (Tekinalp, 2013, 682). Bununla birlikte, Gazi- 
antep sınırları içinde, duvar resimleri yapan Antepli halk sanatçıları hakkındaki bilgiler oldukça sinırlıdır. Ancak, resimlerin üslupları göz önünde bulundurulduğunda, ismi bilinmeyen birden çok yerel sanatçının varolduğu anlaşılmaktadır.

Gaziantep, Şahinbey İlçesi’nde incelediğimiz üç duvar resimli Antep evinden ikisinde Bekir ismine rastlamaktayız. Sanatçının ismi bir evde "Bekri" bir diğer evde "Bekir" şeklinde yazılmıştır. Bunun nedeni, o dönemde Latin Alfabesine yeni geçilmesi olabilir. Suyabatmaz Mahallesi, Müftüoğlu Sokak, No: 5'te yer alan resimdeki alemlerden anlayabileceğimiz gibi, buras1 Müslüman bir yönetici evi ya da kasrıdır (Fig. 20). Ayrıca yelkenli gemilerin dolaştığı büyük nehir de Bostancı Mahallesi, Mektep Sokak, No: 2'deki Gize Piramitleri tasvirinden dolayı, Nil Nehri olarak yorumlanabilir (Fig. 13). Sanatçının betimlediği ağaçların türleri ve coğrafi özellikler göz önünde bulundurulduğunda, bu manzara tasvirinin de Mısır'a ait olduğu düşünülebilir. Mısır, Osmanlı Dönemi’nde önemli bir merkezdir. Bu nedenle Osmanlı Dönemi duvar resimlerinde Mısır tasvirleri görmemiz olağandır. Benzer şekilde Gaziantep'te bulunan başka evlerde de Misır tasvirine rastlanmaktadir.

Araştırmamız kapsamındaki bir diğer halk sanatçısı Şemsi'nin, konu seçimi bakımından Avrupa'ya ait yerleşim yerlerini resmettiği anlaşılmaktadır. Göğüş Evi'nde görülen resimler, aynı bölgenin, farklı açılardan çizilen manzaralarıdır. Pelin Şahin Tekinalp tarafından incelenen, Gaziantep Mehmet Hayri Atay Evi’nde de Şemsi ismine rastlanmaktadır (Tekinalp, 2013, 191208). 1915 civarında inşa edildiği düşünülen evin sahibi Mehmet Hayri Atay, İstanbul ve Halep'le bağlantıları olan bir tüccardır. Evin başodasının tavan eteğinde yirmi, duvarlarında ise iki resim bulunmaktadır. Tavan eteğine; Dolmabahçe Sarayı, Tac Mahal, Halep Kalesi ve Misır Piramitleri gibi önemli merkezlerin simgeleri tasvir edilmiştir (Tekinalp, 2013, 196-200). Pelin Şahin Tekinalp, Bekir'in resimlerinde de görülen Misır tasvirinin duvar resimlerinde yer almas1nın nedenini:

“1813'den sonra İtalyan Belzoni ile başlayan piramitlere ilgi artarak
devam etmiştir. Avrupa'da doğu ilgisi 19. yüzyılda Oryantalizm akımına
dönüşü̈ş, Ejiptoloji kürsüleri açılmıs ve pek çok seyyah, arkeolog,
ressam Mısır'a giderek çalışmalar yapmışlardır. Anlaşılacağ̀ üzere
Mısır, 19. yüzyıldan itibaren sanat üzerinde çok etkin bir merkez duru-
muna gelmiştir. 19. yüzyılın ilk yarısında Antep/Nizip - Mısır savaşı,
l882'de Osmanlı Imparatorluğu'na bağlı olan Mısır'ın Ingilizler tara-
findan işgali önemli tarihi olaylardır. Atay Evi'nde duvar resminde
piramitlerin yer alması tarihi olayların yanı sıra Avrupa üzerinden öğre-
nilen Oryantalizm'in bir sonucu gibi görülebilir” şeklinde açılamakta-
dır (Tekinalp, 2013, 201).

Atay Evi'nde bulunan ve tavan eteğindekilere nazaran daha büyük boyutlara sahip duvar resimleri, hayali manzaralardan oluşmaktadır. Bunlardan birinde "Şemsi Mehmet" imzası ve "1932" tarihi görülmektedir. Pelin Şahin Tekinalp'in, Mehmet Hayri Atay'ın kızından öğrendiğine göre; sanatçı, babası tarafından İstanbul'dan getirtilmiştir (Tekinalp, 2013, 205).

Şemsi Mehmet'in resimlediği Göğüş Evi ve Atay Evi karşılaştırıldığında, Atay Evi'ndeki resimlerin, Göğüş Evi'ne göre daha ayrıntılı ve özenli çizilmiş olduğu gözlenmiştir. Göğüş Evi'nin sahibi, Atay Evi'ndeki duvar resimlerini beğenmiş ve sanatçının kendi evinde de çalışmasını istemiş olabilir. Büyük ihtimalle sanatçı, Göğüş Evi'nin resimlerini diğerine göre daha kısa bir zaman sürecinde yapmıştır. Bekir'e ait resimlerin 1935'te yapıldı̆̆ını, resminin üzerine yazdığı tarihten biliyoruz. Şemsi'nin Gögüş Evi'ndeki resimlerinde herhangi bir tarih yazmama- 
sına rağmen, Atay Evi'nde yer alan 1932 tarihinden yola çıarak, bu evdeki resimlerin de yaklaşık aynı yıllara ait olduğunu düşünmekteyiz.

Bekir, Antepli yerel bir halk sanatçısıdır. Özellikle Mısır tasviri göz önüne alındığında, konu seçimi bakımından, İstanbul'dan getirtilen Şemsi Mehmet'ten etkilenmiş olduğu görülmektedir. Bekir ve Şemsi'nin resmettiği Mısır tasvirinin üslubu karşılaştırıldığında, Şemsi’nin daha yetkin bir sanatçı olduğu açık bir şekilde anlaşılmaktadır (Fig. 13) (Şemsi'nin Mısır tasviri için bkz. Tekinalp, 2013, 201). Bekir, resimlerinde figürlere yer vermiştir. Anadolu duvar resimlerinde figürlü tasvirlere az rastlanmaktadır. Figür, Türk evlerinde genellikle av ve savaş sahnelerinde karşımıza çıkarken, Rum ve Ermeniler gibi azınlık evlerinde daha çok dini ve mitolojik öğelerle duvarları süslemiştir. Gaziantep’te incelediğimiz figürlü resimlerin Türk Mahallesi’nde bulunması ise istisnaî bir durumdur. Bekir'in tüm resimlerinde görülen ve aynı kompozisyonda çizilmiş olan patika yol ve bu yolun başında duran figürler, gökyüzündeki kuşlar ve bazılarında bulunan yelkenli gemiler masalsı bir hava yaratmaktadır. Bu tasvirlerin, Şemsi'nin resimlerinin etkisiyle, fotoğraf/kartpostaldan ilham alınarak, sanatçının hayal dünyasında yeniden biçim bulmuş olduğunu söyleyebiliriz.

19. yüzyılın ikinci yarısında icadıyla birlikte fotoğraf, Osmanlı İmparatorluğu'nun yaşamına hızlı bir şekilde giriş yapmıştır. Fotoğrafın Anadolu'ya yayılması ise genellikle kartpostal ile gerçekleşmiştir. Anadolu duvar resimlerinde, fotoğrafin etkin bir şekilde kullanılması olası bir durumdur. Özellikle İstanbul'da saray ve köşklerde bu tür uygulamalara rastlanmaktadır (Tekinalp, 2000, 226-229). Gaziantep duvar resimlerinde de görsel bir öğe olarak fotoğraf ve kartpostal, duvar resmi sanatçılarına ilham kaynağı olmuştur (Tekinalp, 2013, 679-686).

Sonuç olarak, üç duvar resimli Antep evini incelediğimiz bu çalışmamızda, Anadolu duvar resimleri bakımından önemli bir unsur olan "halk sanatçısı" kategorisine değinilmiş ve iki isim tanıtılmıştır. Sanatçıların yaşadığı tarih dikkate alındığında, Osmanlı Dönemi Anadolu duvar resmi geleneğinin, Cumhuriyet Dönemi’nde de halk sanatçıları tarafından devam ettirildiği anlaşılmaktadır.

\section{KAYNAKÇA}

Aksel, M. (1974). “Bir Halk Ressamı: Mehmed Hulûsi”. Türkiyemiz, 13, 15-18.

Aksel, M. (2010). Anadolu Halk Resimleri. İstanbul: Kapı Yayınları.

Aksoy, Ö. A. (1961). “Yapı”. Gaziantep Kültür Dergisi, Cilt 4, Sayı 41, 21.

Anonim, (2005). Gaziantep Kültür Envanteri. Gaziantep, T.C. Gaziantep Valiliği.

Arık, R. (1975). “Anadolu’da Bir Halk Ressamı: Zileli Emin”. Türkiyemiz, 16, 8-13.

Arık, R. (1988). Batılllaşma Dönemi Anadolu Tasvir Sanatı. Ankara: Kültür ve Turizm Bakanlığı Yayınları.

Arpacıoğlu, A. (1961). “1872 Yılında Yapılmış Bir Antep Evi”. Gaziantep Kültür Dergisi, Cilt 4, Sayı 47, $16-17$.

Arslan, C. (2010). "Elâzı̆̆g/Hüseynik (Ulukent) Havuzbaşı ve Harput Panoraması”. Zeitschrift für die Welt der Türken (Journal of World of Turks), 151-177.

Atalar, A. (2004). Osmanlı Dönemi Antep Evleri. İstanbul: Merinos Halı A.Ş. Yayınları.

Balta, E. (2007). Sinasos: Mübadeleden Önce Bir Kapadokya Kasabası. Çev.: Ari Çokana. İstanbul: Birzamanlar Yayıncıllk.

Cantay, G. (1980). “Zileli Emin Usta’nın Bilinmeyen İki Eseri”. Bedrettin Cömert'e Armağan, 497-503.

Çal, H. (1987). "Şeyh Nasreddin (Nusret) Türbesi”. Türk Tarihinde ve Kültüründe Tokat Sempozyumu, 26 Temmuz 1986, 427-459.

Çam, N. (2006). Türk Kültür Varllkları Envanteri: Gaziantep 27. Ankara: Türk Tarih Kurumu Yayınları.

Çayan, S. (2012). Geleneksel Antep Evlerinde Kalem İşi Bezeme ve Duvar Resimleri. Yayınlanmamış 
Yüksek Lisans Tezi. Atatürk Üniversitesi, Sosyal Billimler Enstitüsü, Erzurum.

Ecesoy, Y. (2011). Osmanlı Dönemi Anadolu Duvar Resimlerinde İstanbul Tasvirleri. Yayınlanmamış Yüksek Lisans Tezi. Erciyes Üniversitesi, Sosyal Billimler Enstitüsü, Kayseri.

Germaner, S. (2011). "XIX. Yüzyılda İstanbul ve Kahire: Sanat Ortamı ve Patronaj”. Günsel Renda'ya Armağan, 125-133.

Gürçağlar, A. (2002). "Kahire Mevlevihanesi Semahanesi’nde Yer Alan Hayali Kent Tasvirleri”. Uluslararası Sanat Tarihi Sempozyumu Prof. Dr. Gönül Öney'e Armağan, 10-13 Ekim 2001,343-350.

Güzelbey, C. C. (1960). “Gaziantep’te Yapıc1lık”. Gaziantep Kültür Dergisi, Cilt 3, Sayı 35-36, 4-14.

Güzelhan, M. (1959). Ayıntap Tarihinden Notlar: Dülük, Ayni Bedrettin, Ayıntabın Tarihte Ŭgradı̆g Istilalar. Gaziantep: Gaziantep Kültür Derneği Yayınları.

İnankur, Z. (2011). “İstanbul ve Kahire'de 19. Yüzy1l Sanatı”. Günsel Renda'ya Armağan, 133-139.

Kalender, E. (1999). Gaziantep Abdülkadir Kimya Evi Duvar Resimleri. Duman Ofset.

Özbek, Y. (2005). Mustafapaşa (Sinasos) Evlerinde Duvar Resimleri. Kayseri, Mustafapaşa Yerel Gündem 21 Kent Konseyi.

Öztahtacı, S. (1961). “Kış ve Gaziantep Evleri”. Gaziantep Kültür Dergisi, Cilt 4, Sayı 37, 10.

Pekak, S. M. (2010). "Kasaba, Kilise, Ressam (Sinasos, Mustafapaşa Aziz Basileios Kilisesi, Kostis Meletiadis)”. Arkeoloji ve Sanat Dergisi, Sayı 133, 77-100.

Pınarbaşı, S. Ö. (2001). “Türk Halk Resmi Geleneğinin Türk Resim Sanatına Etkileri”. Kaynak Dergisi; Türk Kültür Merkezi Sofya Bulgaristan, Sayı 27, 14-15.

Renda, G. (1977). Batılılaşma Döneminde Türk Resim Sanatı 1700-1850. Ankara: Hacettepe Üniversitesi Yayınları.

Renda, G. (1986). "Göreme'de Korunması Gereken Bir Ev”. III. Araştırma Sonuçları Toplantısı Ankara, 20-24 Mayls 1985, 103-118.

Renda, G. (1997). "Painted Decoration in $19^{\text {th }}$ Century Ottoman Houses: Damascene Connection”. Ed. A. Temimi. Corpus D'Archeologie Ottomane, 91-105.

Renda, G., \& Erol, T. (1980) Başlangıcından Bugüne Çağdaş Türk Resim Sanatı Tarihi. Cilt 1. İstanbul: Tiglat Yayınları.

Sözen, M. (1972). “Köyde bir Duvar Resmi”. Türkiyemiz, 31-33.

Tanman, B. (1993). "Merzifon Kara Mustafa Paşa Camii Şadırvanının Kubbesinde Zileli Emin'in Yarattığı Osmanlı Dünyası ve Bu Dünyaya Yansıyan Kişiliğı’. Sanat Tarihinde İkonografik Araştırmalar Güner İnal'a Armağan, 491-521.

Tekinalp, P. Ş. (2000). "Duvar Resimlerinde Fotoğrafın Etkisi Üzerine Örnekleme; Şale Köşkü’nden Bir Grup Resim”, Uluslararası Sanatta Etkileşim Sempozyumu, 25-27 Kasım 1998, Hacettepe Üniversitesi Edebiyat Fakültesi Sanat Tarihi Bölümü, 226-229.

Tekinalp, P. Ş. (2002). "Batılılaşma Dönemi Duvar Resmi”. Türkler. Eds. H. C. Güzel; K. Çiçek, \& S. Koca. C. 15, 440-447. Ankara.

Tekinalp, P. Ş. (2013). "Manzaralı Oda: Atay Evi'nden Egzotik Manzaralar”. Hacettepe Üniversitesi Edebiyat Fakültesi Dergisi/Journal of Faculty of Letters, Cilt 30, Say1 2 (Aral1k/December), 191-208.

Tekinalp, P. Ș. (2013). "Palais du Trocadéro in Ayntab/Antep". 14. Uluslararası Türk Sanatları Kongresi Kitabl, 679-686.

Ülkü, A. (1961). “Gaziantep’te Antep Harbinden Önce Yapılmış Bir Türk Evi”. Gaziantep Kültür Dergisi, Cilt 4, Say1 45, 21-23.

Ünal, Z. G. K. (2007). “Antep Evi: Günlük Yaşamın Özel Alanları”. Gaziantep: Dört Yanı Dağlar Bağlar. Yapı Kredi Yayınları, 177.

Weber, S. (2006). "Zeugnisse Kulturellen Wandels. Stadt, Architektur Und Gesellschaft Des Osmanischen Damaskus in 19. Und Frühen 20. Jahrhundert”. EJOS, IX (2006), No. 1, I-X, 1-1014?

Yener, Ş. S. (1960). “Gaziantep’te 182 Yıllık Bir Ev”. Gaziantep Kültür Dergisi, Cilt 3, Sayı 31, 19-20. 
